


\title{
CONCEPTION RATES AND SEX CONCOMITANT OF BALI CALVES FOLLOWING OESTRUS SYNCHRONIZATION AND ARTIFICIAL INSEMINATION OF FROZEN- SEXED SEMEN UNDER FARM CONDITIONS
}

\author{
S. Said ${ }^{1}$, C. Arman ${ }^{2}$ and B.Tappa ${ }^{1}$ \\ ${ }^{1}$ Research Center for Biotechnology, Indonesian Institute of Sciences, \\ Jl. Raya Bogor Km. 46, Cibinong 16911 - Indonesia \\ ${ }^{2}$ Faculty of Animal Science, Mataram University, West Nusa Tenggara, \\ Jl. Majapahit No. 62, Mataram, Lombok, NTB 83125 - Indonesia \\ Corresponding E-mail:syahruddinsaid01@gmail.com
}

Received January 07, 2014; Accepted Fabruary 19, 2014

\begin{abstract}
ABSTRAK
Penelitian ini bertujuan untuk menentukan angka kebuntingan dan kelahiran sapi Bali sesudah sinkronisasi estrus dan inseminasi buatan (IB) dengan semen beku sexing serta kesesuaian jenis kelamin anak. Penelitian dilakukan pada dua lokasi peternakan di Kabupaten Lombok Barat. Sinkronisasi estrus dilakukan melalui pemberian satu suntikan $5 \mathrm{cc}^{\text {Lutalyse }}{ }^{\circledR}$ yang mengandung $25 \mathrm{mg}$ PGF $_{2 \alpha}$ (Lutalyse, Sterile Solution, Pharmacia Animal Health) secara intra muscular. Pengamatan dilakukan pada sapi yang memberikan respon dan diinseminasi pada saat estrus. IB juga langsung dilakukan pada sapi-sapi yang menunjukkan birahi alami. Diagnosa kebuntingan dilakukan melalui palpasi rektal pada hari ke-90. Pada Peternakan 1, angka kebuntingan sapi-sapi yang mendapat perlakuan dan yang tidak mendapat perlakuan $\mathrm{PGF}_{2 \alpha}$ masing-masing sebesar 29/63 (46,03\%) dan 71/75 (94,66\%). Pada Peternakan 2, nilainilai yang bersesuaian masing-masing adalah 38/89 (42,70\%) dan 10/23 (43,48\%). Angka kelahiran anak pada kedua farm diperoleh $100 \%$. Angka kesesuaian jenis kelamin untuk anak betina yang lahir di Peternakan 1 adalah 94.00\%, sedangkan di Peternakan 2, untuk anak sapi yang terlahir jantan adalah 93.75\%. Dibawah kondisi penelitian ini, sinkronisasi estrus yang diikuti dengan IB semen beku hasil sexing tampaknya dapat diaplikasikan di lapang sehingga menghasilkan angka kebuntingan dan kelahiran anak yang pantas diterima, serta angka kesesuaian di atas 90\% untuk masing-masing jenis kelamin betina maupun jantan.
\end{abstract}

Kata kunci: inseminasi buatan, sapi Bali, sinkronisasi estrus, semen beku-sexing, angka kesesuaian jenis kelamin

\begin{abstract}
The objective of this study was to determine the conception rate of Bali cattle synchronized and artificially inseminated with frozen thawed sexed-semen concomitant with its calves sex. This experiment was conducted in two cattle farms in West Lombok Regency. Oestrus was synchronized with a single injection i.m. of $5 \mathrm{cc}$ Lutalyse $^{\circledR}$ containing $25 \mathrm{mg}$ of $\mathrm{PGF}_{2 \alpha}$ (Lutalyse, Sterile Solution, Pharmacia Animal Health). The observation was conducted in the responded cattle that artificially inseminated at once oestrus. Pregnancy diagnosis was conducted by rectal palpation at about day-90. In Farm 1, the conception rate (CR) of $\mathrm{PGF}_{2 \alpha}$-treated and non-treated animals were 29/63 (46.03\%) and $71 / 75$ (94.66\%), respectively. However, in Farm 2 the corresponding values were 38/89 (42.70\%) and $10 / 23(43.48 \%$ ), respectively. CR in both farms were found being $100 \%$. Sex concomitant rate for female calves born in Farm 1 was found being 94/100 (94.00\%), whilst in Farm 2, sex concomitant rate for male calves born was recorded to be $45 / 48$ (93.75\%). It was concluded that under farm conditions oestrus synchronization using $\mathrm{PGF}_{2 \alpha}$ in conjunction with $\mathrm{AI}$ of frozen-thawed Bali sexed spermatozoa might be used with acceptable conception and calving rates that above $90 \%$ concomitant with its respective calve-sex rates.
\end{abstract}

Keywords: artificial insemination, Bali cattle, frozen sexed-semen, oestrus synchronization, sex concomitant rate 


\section{INTRODUCTION}

Artificial insemination (AI) technology is the most effective tool for genetic improvement in cattle. The AI service in West Nusa Tenggara (WNT) Province began in the 1976 using frozen semen from Simmental, Limousin, Brangus, Brahman, Friesian Holstein bulls among others. In enabling sustainable production of cattle crossbreds, AI program has to be developed in order to increase the socio-economic status of village farmers as the program had a positive impact on the livestock industry in the province. Thus, in the future AI will continue to play an important role as one of the reproductive technologies for cattle farming in WNT Province.

The added value of AI technology can be increased especially when supported by the technology of sperm separation to get calves with pre-determined sex. Currently, the only known means of effectively producing separate populations of $\mathrm{X}$ and $\mathrm{Y}$ sperm in mammals is thorough the use of DNA differentiation by highspeed flowcytometry (Johnson et al., 1989) Applicable to virtually all mammals, this method can produce population of $\mathrm{X}$ or $\mathrm{Y}$ sperm with greater than $90 \%$ purity and subsequent offspring whose phenotypic sex is consistent with initial purity of the stored sperm population (Rath and Johnson, 2008).

Accuracy of sperm sexing by flowcytometry is estimated to reach 90\% (Seidel and Garner, 2002), whereas Johnson and Seidel (1999) using this technique obtained $85-95 \%$ of births according to sex. However, the procurement of the equipment in the university laboratories and AI Centers in Indonesia is difficult to achieve as the price is very expensive. It seems that the use conventional methods of sperm separation need to be applied under WNT Province. Some conventional methods that have been used previously to separate sperm bearing X-and Ychromosomes included sedimentation, electrophoresis, Sephadex G-50 filtration, centrifugation, column albumin (BSA) and other methods (Garner, 2001). Hafez and Hafez (1993) stated that because of the differences in the weight, density, or size of the $\mathrm{X}$ and $\mathrm{Y}$ chromosomes as a result of differences in the size of different components of the sperm, $\mathrm{X}$ and $\mathrm{Y}$ sperm can be separated. $X$ chromosome is larger and carries more DNA than the smaller Ychromosomes (Gordon, 2004).

According to Hafez and Hafez (1993), only two laboratory methods for separation of animal and human $\mathrm{X}$ and $\mathrm{Y}$ sperm appear valid, reproducible, and clinically applicable: albumin separation, which yields $75 \%$ to $80 \%$ Y sperm, and Sephadex filtration, which yields $70 \%$ to $75 \%$ $\mathrm{X}$ chromosome. In Indonesia using column albumin method for sperm separation, Kaiin et al. (2005) reported that the percentages of motility of Hongarian frozen-thawed sexed-sperm yields $44 \%$ sperm bearing X- and $43 \%$ sperm bearing Ychromosomes.

Most of the previous works conducted to examine the effect of sex-sorted sperm on fertility of cows reared with AI were carried out either on research stations or under ranch management system. However, adequate information is lacking on performance of AI in conjunction with sexedsemen under farm conditions. Therefore, the present study was conducted with the objective to examine the conception rate of Bali cattle synchronized and artificially inseminated with frozen-thawed Bali sexed-semen and its sex concomitant under farm conditions in WNT Province.

\section{MATERIALS AND METHODS}

\section{Semen Collection and Processing of Sexed- Sperm}

Semen collection and processing of sexedsperm were conducted at Regional AI Center, Banyumulek, WNT Province. Semen was collected from four bulls by using artificial vagina once a week. Each bull to be ejaculated was allowed to mount a teaser bull. Ejaculated semen was observed macroscopically for volume, color, smell, consistency and $\mathrm{pH}$; and microscopically for mass and progressive motility, concentration, live sperm, abnormality and intact acrosome. Semen volume was recorded directly from the graduated semen collection tube. Each ejaculate having less than $70 \%$ sperm motility was discarded.

Separation of spermatozoa was carried out by means of albumin column method. Briefly, semen concentration of $300\left(\mathrm{x} 10^{6}\right) \mathrm{cell} / \mathrm{mL}$ was suspended on the top of gradient albumin column. Each semen fraction was collected and put into centrifuge tube, then washed using Brackett \& Oliphant (BO) medium and centrifuged at 2500 r.p.m for $10 \mathrm{~min}$. The separated sperm was then diluted in tris-buffered diluent containing $20 \%$ egg yolk and glycerol as cryoprotectant (v/v). The diluted separated-sperm was then filled into 0.25 
$\mathrm{mL}$ straw and sealed, cooled at $5^{\circ} \mathrm{C}$ (equilibration) for $4 \mathrm{~h}$. Finally, the processed sexed-sperm was frozen and stored in liquid nitrogen $\left(-196^{\circ} \mathrm{C}\right)$.

\section{Oestrus Synchronization and AI of Sexed- Sperm}

This experiment were conducted from November 2011 to February 2012 at 250 cows in two cattle farms, in West Lombok Regency where all private cattle owned by farmers and taken care by management of small holders, hence the management were similar in each farm. Selection of animals was conducted by per rectum palpation of corpus luteum functional of the ovaries. Animals with palpable corpora lutea were then synchronized with a single i.m. injection of $5 \mathrm{cc}$ Lutalyse ${ }^{\circledast}$ containing $25 \mathrm{mg}$ of $\mathrm{PGF}_{2 \alpha}$ (Lutalyse, Sterile Solution, Pharmacia Animal Health). The response cattle were artificially inseminated with frozen thawed sexed-semen once oestrus. Artificial insemination with frozen thawed sexedsemen was also performed directly to those animals observed in natural oestrus.

All animals in Farm 1 and Farm 2 were inseminated with frozen-thawed $\mathrm{X}$ - and Y-bearing spermatozoa, respectively. Pregnancy diagnosis was conducted to each cattle by rectal palpation at about 90 days after last insemination.

\section{Data Analysis}

Data regarding to semen parameters recorded were analyzed using analysis of variance (ANOVA). The difference among means was tested by Duncan's Multiple Range Test. Conception rates and sex concomitant rate were analyzed using Chi-square and treatment differences would have been considered different at an alpha level of 0.05 .

\section{RESULTS AND DISCUSSION}

\section{Characteristics of Fresh Semen}

The overall characteristics of Bali bull fresh semen are presented in Table 1. The mean volume of ejaculate observed throughout the study was $6.47 \pm 2.52 \mathrm{~mL}$ with the color of semen varied from white to cream and the smell from normal to specific as well as consistency from moderate to viscous. The $\mathrm{pH}$ of fresh semen was 7 (alkaline), indicated normal $\mathrm{pH}$ of Bali bull semen. The mean percentages of mass motility observed in this study varied from good (++) to very good (+++), while the progressive motility was $75.00 \pm 4.33 \%$. The average sperm
Table 1. Evaluation of Macroscopic and Microscopic of Fresh Bali Bull Semen

\begin{tabular}{ll}
\hline \multicolumn{1}{c}{ Semen Characteristics } & Mean \pm SD $(\mathrm{n}=9)$ \\
\hline Volume $(\mathrm{mL})$ & $6.47 \pm 2.52$ \\
Color & white to cream \\
Smell & normal to specific \\
Consistency & moderate to viscous \\
$\mathrm{pH}$ & 7 \\
Mass motility & ++ to +++ \\
Motility $(\%)$ & $75.00 \pm 4.33$ \\
Concentration $\left(\mathrm{x} 10^{6}\right.$ sperm/ & $1.741 .00 \pm 421.01$ \\
mL) & $90.44 \pm 3.84$ \\
Intact plasma membrane $(\%)$ & $3.78 \pm 0.83$ \\
Abnormality $(\%)$ &
\end{tabular}

++=good, +++=very good

concentration was $1.741 .00 \pm 421.01 \quad\left(\mathrm{x} 10^{6}\right)$ spermatozoa/mL. The mean percentages of intact plasma membrane and the abnormality of spermatozoa noted in this study were $90.44 \pm$ $3.84 \%$ and $3.78 \pm 0.83 \%$, respectively.

The semen characteristics of Bali bulls observed in this study were similar to those reported by previous authors. Kaiin et al. (2005) reported that semen volume of Hongarian bull was $7.00 \pm 2.00 \mathrm{~mL}$ which was slightly lower than semen volume recorded in this study, that was $6.47 \pm 2.52 \mathrm{~mL}$; however, higher than that of Ongole Grade Cattle (PO), that was $5.56 \pm 1.43$ $\mathrm{mL}$ reported by Rasyid et al. (2006). The color, consistency, $\mathrm{pH}$, smell and mass motility of Bali bulls semen recorded in this study agreed with the findings of Kaiin et al. (2005) in Hongarian bull semen. The mean percentage progressive sperm motility observed in this study was lower $(75.00 \pm$ $4.33 \%$ ) than that of Kaiin et al. (2005), who recorded $79.60 \pm 6.00 \%$ progressive sperm motility in Hongarian bull semen. Though, it was higher compared to progressive sperm motility of PO bull observed by Rasyid et al. (2006), that was $71.36 \pm 16.45 \%$. The present study shows that sperm concentration of $1.741 .00 \pm 421.01\left(\mathrm{x} 10^{6}\right)$ sperm $/ \mathrm{mL}$ was higher than that of PO bull's semen, that was 1.651.27 $\pm 813.46\left(\mathrm{x} 10^{6}\right)$ sperm $/ \mathrm{mL}$ (Rasyid et al., 2006) and Hongarian bull's semen, that was $1025.00 \pm 225.00\left(\mathrm{x} \mathrm{10} 0^{6}\right)$ sperm $/ \mathrm{mL}$ (Kaiin et al., 2005). In addition, the 
intact of plasma membrane was $90.44 \pm 3.84 \%$, which was higher than that observed by Kaiin et al. (2005), that was $48.60 \pm 9.60 \%$. Similarly, Bali bull had lower sperm abnormality $(3.78 \pm 0.83 \%)$ than that of Hongarian bull $(11.60 \pm 5.10 \%)$ and PO bull's semen, that was $(7.48 \pm 5.88 \%)$. The difference in these characteristics of semen might be attributed to differences in the breed, age, body size, level of nutrition, frequency of semen collection, and various other factors (Kaiin et al., 2005).

\section{Characteristics of $\mathrm{X}$ - and Y-bearing Spermatozoa after Sexing and Freezing of Fresh Semen}

Table 2 shows the characteristics of fresh semen, $\mathrm{X}$ and $\mathrm{Y}$ bearing spermatozoa after sexing and freezing of fresh semen in Bali bulls. In this study, the averages motility and intact plasma membrane (acrosome) of spermatozoa decreased significantly $(\mathrm{P}<0.05)$ when fresh semen was sexed into $\mathrm{X}$ - and Y-bearing spermatozoa, and these continue decreased significantly $(\mathrm{P}<0.05)$ in frozen thawed sexed-semen. However, no significant differences $(\mathrm{P}>0.05)$ was observed in the mean percentages of motility, intact plasma membrane and abnormality of spermatozoa between $\mathrm{X}$ and $\mathrm{Y}$ bearing spermatozoa after sexing and freezing of fresh semen. The decreased in motility and intact plasma membrane of spermatozoa might be due to the effect of separation of spermatozoa by centrifugation that caused damage membrane cells. It was noted that the mean percentages of abnormalities of $\mathrm{X}$ and $\mathrm{Y}$ bearing spermatozoa did not change much when fresh semen was frozen.

Data shown in Table 2 clearly indicate that sexing sperm using egg albumin technique is still able to maintain motility and viability of frozenthawed spermatozoa. The mean percentage of motility after thawing of frozen semen was slightly above 45 percent, so that the frozen thawed Bali sexed-semen might be used for $\mathrm{AI}$ in cattle.

\section{Oestrus Synchronization Response}

The percentages of cattle showing oestrus in treated and non-treated $\mathrm{PGF}_{2 \alpha}$ of Bali cattle at different farms are presented in Table 3. The number of animals that showed signs of oestrus in non-treated $\mathrm{PGF}_{2 \alpha}$ was significantly higher (76.53 \%) than that of treated $\mathrm{PGF}_{2 \alpha}(41.45 \%)$ in Farm 1. Conversely, signs of oestrus were significantly higher in treated $\mathrm{PGF}_{2 \alpha}$ animals $(58.55 \%)$ than that of non-treated $\mathrm{PGF}_{2 a}(23.47 \%)$ in Farm 2. However within non-treated $\mathrm{PGF}_{2 \alpha}$ animals, oestrus was observed significantly higher in Farm $1(76.53 \%)$ than that of Farm $2(23.47 \%)$.

Oestrus in all treated animals occurred within 2-3 days after injection of $\mathrm{PGF}_{2 \alpha}$. It seems that $\mathrm{PGF}_{2 \alpha}$ lutealized corpus luteum so that progesterone levels decreased. Lower levels of progesterone will in turn affect the increase of FSH levels which stimulate maturation of follicle development that finally induce onset of oestrus in cattle. Though, it was observed that characteristics of oestrus detected in both treatedand non-treated $\mathrm{PGF}_{2 \alpha}$ animals were quite similar in terms of physical changes of the reproductive tract such as vulvular oedema and mucus discharge. This is in agreement with the findings of Amjad et al. (2006) who observed in Sahiwal cows.

\section{Conception Rates}

Data regarding to the conception rate of Bali

Table 2. Characteristics of Fresh Semen, X and Y Bearing Spermatozoa After Sexing and Freezing Fresh Semen

\begin{tabular}{|c|c|c|c|c|c|}
\hline \multirow{2}{*}{$\begin{array}{l}\text { Semen } \\
\text { Characteristics }\end{array}$} & \multirow{2}{*}{$\begin{array}{c}\text { Fresh Semen } \\
\text { Mean } \pm \text { SD }\end{array}$} & \multicolumn{2}{|c|}{ Fresh Sexed-Semen } & \multicolumn{2}{|c|}{ Frozen-Thawed Sexed-Semen } \\
\hline & & $\begin{array}{c}\text { X Sperm } \\
\text { Mean } \pm \text { SD }\end{array}$ & $\begin{array}{c}\text { Y Sperm } \\
\text { Mean } \pm \text { SD }\end{array}$ & $\begin{array}{c}\text { X Sperm } \\
\text { Mean } \pm \text { SD }\end{array}$ & $\begin{array}{c}\text { Y Sperm } \\
\text { Mean } \pm \text { SD }\end{array}$ \\
\hline Motility (\%) & $75.00 \pm 4.33^{\mathrm{a}}$ & $71.67 \pm 2.36^{\mathrm{b}}$ & $72.78 \pm 2.48^{b}$ & $47.78 \pm 2.48^{\mathrm{c}}$ & $45.56 \pm 1.57^{\mathrm{c}}$ \\
\hline Intact sperm (\%) & $90.44 \pm 3.84^{\mathrm{a}}$ & $86.11 \pm 3.14^{\mathrm{b}}$ & $82.67 \pm 3.89^{\mathrm{b}}$ & $68.89 \pm 4.58^{\mathrm{c}}$ & $65.56 \pm 5.42^{\mathrm{c}}$ \\
\hline Abnormality (\%) & $3.78 \pm 0.83^{\mathrm{a}}$ & $4.11 \pm 0.58^{\mathrm{a}}$ & $4.07 \pm 0.85^{\mathrm{a}}$ & $4.13 \pm 0.65^{\mathrm{a}}$ & $4.19 \pm 0.50^{\mathrm{a}}$ \\
\hline
\end{tabular}

$a, b, c=$ different superscripts in the same row indicated significantly different $(\mathrm{P}<0.05)$.

$\mathrm{SD}=$ standard deviation. 
cattle after artificially inseminated with frozen thawed sexed-semen either in treated and nontreated $\mathrm{PGF}_{2 \alpha}$ are presented in Table 4.

Results of the study showed that conception rate of non-treated $\mathrm{PGF}_{2 \alpha}$ animals was significantly higher $(94.66 \%)$ than that of treated animals $(46.03 \%)$ in Farm 1. In addition within treated $\mathrm{PGF}_{2 \alpha}$ animals, conception rate was significantly higher in Farm 1 than that of Farm 2 (46.03\% vs $42.70 \%)$. Similarly, within non-treated $\mathrm{PGF}_{2 \alpha}$ animals, conception rate was significantly higher in Farm 1 than that of Farm $2(94.66 \%$ vs $43.48 \%$ ).

Low conception rates in Farm 2 either in treated or non-treated $\mathrm{PGF}_{2 \alpha}$ animals may be caused the corpus luteum of the animals that were too young (before day 5) to respond at practical levels. Bearden et al. (2004) suggested that prior

Table 3. The Percentages of Animals Showing Oestrus in Treated and Non-treated $\mathrm{PGF}_{2 \alpha}$ Bali Cattle at Different Farms

\begin{tabular}{lcc}
\hline & \multicolumn{2}{c}{$\begin{array}{c}\text { Number of Animals Showing Oestrus } \\
(\%)\end{array}$} \\
\cline { 2 - 3 } Loction & Treated PGF $_{2 \alpha}$ & $\begin{array}{c}\text { Non-treated } \\
\text { PGF }_{2 \alpha}\end{array}$ \\
\cline { 2 - 3 } & $63(41.45)^{\mathrm{a}, \mathrm{c}}$ & $75(76.53)^{\mathrm{b}, \mathrm{c}}$ \\
Farm 1 & $89(58.55)^{\mathrm{a}, \mathrm{c}}$ & $23(23.47)^{\mathrm{b}, \mathrm{d}}$ \\
Total & $152 \quad(100)$ & $98 \quad(100)$ \\
\hline
\end{tabular}

$a, b$ : different superscripts in the same row indicate significantly different $(\mathrm{P}<0.05)$.

$\mathrm{c}, \mathrm{d}$ : different superscripts in the same column indicate significantly different $(\mathrm{P}<0.05)$. to day 5, the corpus luteum may not have sufficient receptor sites to respond to normal levels of $\mathrm{GF}_{2 \alpha}$. In addition, metabolic pathways may have not developed sufficiently at this point to allow complete response. The differences in the conception rates between the two locations could also be due to differences in age and physiological state of the animal at the time of treatment, season of the year, dose and chemical nature of $\mathrm{PGF}_{2 \alpha}$ used (Amjad et al., 2006).

Moreover, low conception rates found in Farm 2, both in treated and non-treated $\mathrm{PGF}_{2 \alpha}$ may be due to nutritional effect because of scarcity of fodders during late dry periods and high ambient temperature at the time that treatment was performed in this location. In adequate of feed results in low body condition scores, and may adversely affect the follicular growth and ovulation. Other factor that might cause the differences in CR of cattle is that the distance between the AI center where frozen semen was kept and the farm locations. When inseminators would perform insemination, they had to pick up the semen to AI Centre, then brought it to the farm where its location quite far from the AI Centre, particularly in the case of Farm 2. By having arrived in the farm, it was too late to inseminate the animals. Regardless of location and type of oestrus, it was observed that from total 250 cattle used in this study the overall conception rate of Bali cattle was found to be $59.20 \%$.

\section{Calving Rate and its Concomitant with Calves Sex}

The calving rate of the artificially inseminated frozen sexed-semen and its concomitant calves sex was shown in Table 5.

Table 4. Conception Rate of Bali Cattle Following Artificial Insemination of Treated and Non-treated $\mathrm{GF}_{2 \alpha}$ at Different Farms

\begin{tabular}{|c|c|c|c|}
\hline \multirow{2}{*}{ Location } & \multicolumn{3}{|c|}{ Conception Rate (\%) } \\
\hline & Total & Treated $\mathrm{PGF}_{2 \alpha}$ & Non-treated $\mathrm{PGF}_{2 \alpha}$ \\
\hline Farm 1 & $100 / 138(72.46)$ & $29 / 63(46.03)^{\mathrm{a}, \mathrm{c}}$ & $71 / 75(94.66)^{b, c}$ \\
\hline Farm 2 & $48 / 112(42.86)$ & $38 / 89(42.70)^{\mathrm{b}, \mathrm{d}}$ & $10 / 23(43.48)^{b, d}$ \\
\hline Total & $148 / 250(59.20)$ & $67 / 152(44.08)$ & $81 / 98$ (82.65) \\
\hline
\end{tabular}

Conception Rate $=$ Number of pregnant animals/number of inseminated animals

$a, b$ : different superscripts in the same row indicated significantly different $(\mathrm{P}<0.05)$.

$c, d$ : different superscripts in the same column indicated significantly different $(\mathrm{P}<0.05)$. 
Table 5. Calving and Sex Concomitant Rates of Artificially Inseminated Using Sexed Semen

\begin{tabular}{lccccccc}
\hline \multirow{2}{*}{ Location } & \multirow{2}{*}{$\begin{array}{c}\text { Number of } \\
\text { Pregnant }\end{array}$} & \multirow{2}{*}{$\begin{array}{c}\text { Number of } \\
\text { Calves Born }\end{array}$} & & \multicolumn{2}{c}{ Sex of Calves } & & \multicolumn{2}{c}{ Sex Concomitant Rates (\%) } \\
\cline { 8 - 9 } \cline { 7 - 8 } & & & Female & Male & & Female & \multicolumn{1}{c}{ Male } \\
\hline Farm 1 & 100 & 100 & 94 & 6 & & $94 / 100(94.00)$ & $6 / 100(6.00)$ \\
Farm 2 & 48 & 48 & 3 & 45 & & $3 / 48(6.25)$ & $45 / 48(93.75)$ \\
Total & 148 & 148 & 97 & 51 & & $97 / 148(65.54)$ & $51 / 148(34.46)$ \\
\hline
\end{tabular}

Calving rate $=$ Number of Calves Born/Number of Pregnant Animals

Data in Table 5 showed that a total 148 out of 250 cows that artificially inseminated with sexed-semen was pregnant and all pregnant animals in both farms had delivered normalappearing offspring successfully. Thus, calving rate was recorded to be $100 \%$. This indicates that all animals which are taken care by the management system of small holders farms could maintain its gestation until delivered.

When AI performed using X-sperm, it was expected that female offspring will be born. Table 5 indicated that the number of female calves born after AI with X-sperm in Farm 1 was 94\%. While the number of male calves born after AI with Ysperm in Farm 2 was 93.75\%. This study indicated that sex concomitant rate was higher for female calves than that of data reported by Said $e t$ al. (2005), who recorded $81 \%$ in Simmental and Friesian Holstein cattle. Data of the study was also found within the range of data of Seidel and Garner (2002), Johnson and Saidel (1999) who separating sperm using flow cytometry that was able to reach expectation of $85-95 \%$ births according to sex of the offspring.

\section{CONCLUSION}

Oestrus synchronization using $\mathrm{GF}_{2 \alpha}$ can be used in conjunction with AI of frozen thawed Bali sexed-spermatozoa under farm conditions with acceptable conception and sex offspring concomitant rates. However, new methods of synchronizing oestrus in Bali cattle need to be sought in order to enhance results from AI with frozen thawed sexed-semen, thereby reduce the period of time required to detect oestrus or eliminate the need of oestrus detection entirely. Further research is needed to more precisely determine the appropriate timing of fixed-time insemination following administration of oestrus synchronization agents and their extended application to Bali cattle in the wider areas.

\section{ACKNOWLEDGMENTS}

This research was supported by Ministry of Research and Technology, the Republic of Indonesia. Appreciation is expressed to Ir. Nasruddin A. W., Head of Regional Artificial Insemination Centre, Banyumulek, West Nusa Tenggara Province by giving permission to use Bali bulls and semen laboratory facilities. Our gratitude is also to the entire team of Animal Research Group in Research Center for Biotechnology LIPI for their assistance in completing this research.

\section{REFERENCES}

Amjad, M., M. Aleem and A. Saeed. 2006. Use of prostaglandin (PGF) to induce oestrus in postpartum Sahiwal cows. Pakistan Vet. J. 26:63-66

Bearden, H. J., J.W. Fuquay and S.T. Willard. 2004. Applied Animal Reproduction. $6^{\text {th }}$ Ed., Pearson, Prentice Hall, New Jersey, p. 238

Garner, D.L., B.L. Gledhill, D. Pinkel, S. Lake, D. Stephenson, M.A. Van Dilla and M.A. Johnson. 1983. Quantification of the X- and Y-chromosome-bearing spermatozoa of domestic animals by flow cytometry. Biol. Reprod. 28:312-321.

Garner, D.L. 2001. Sex-sorting mammalian sperm: Concept to application in animals. J. Andrology. 22: 519-526.

Hafez, E.S.E. 1993. Reproduction in Farm Animals. 6th ed. Lea \& Febiger. Philadelphia Johnson, L.A. and G.E. Seidel Jr. 1999. Current status of sexing mammalian spermatozoa. Theriogenology. 52: 1267-1484. 
Kaiin, E. M., S.S. Ginting, M. Djuarsawidjaja, S. Said and B. Tappa. 2005. Kualitas sperma hasil pemisahan yang dibekukan menggunakan rak dinamis dan statis. Proceedings, National Seminar on Technology of Animal and Veterinary. Bogor, 12-13 September 2005. P 105-111

Pinkel, D., S. Lake, B.L. Gledhill, M.A. Van Dilla, D. Stephenson and G. Watchmaker. 1982. High resolution DNA content measurements of mammalian sperm. Cytometry. 3:1-9.

Rasyid, A., D.B. Wijono and N.H. Krisna. 2006. Aplikasi teknologi pemisahan sperma pada sapi PO. Proceedings, National Seminar on Technology of Animal and Veterinary Sciences. Bogor, 5-6 September 2005. Page. 135-142

Said, S., E.M. Kaiin and B. Tappa. 2005. Produksi anak sapi potong dan sapi perah berjenis kelamin sesuai harapan. Proceedings, National Seminar on Modern Animal Industry II. 19-20 July 2005. P 209-216.

Seidel, G.E. Jr and D.L. Garner. 2002. Current status of sexing mammalian spermatozoa. Reproduction. 124: 733 - 743.

Susilawati, T. 2004. Keberhasilan IB menggunakan semen sexing setelah dibekukan. Proceedings, National Seminar on Technology of Animal and Veterinary, Bogor. P 195-206

Susilawati, T., S.B. Sumitro, Harjopronjoto, Y. Mantara and Nuryadi. 1999. Pola kapasitasi spermatozoa $\mathrm{X}$ dan $\mathrm{Y}$ sapi hasil pemisahan menggunakan filtrasi sephadex dan sentrifugasi gradient densitaspercoll. J. Penelitian Ilmu-ilmu Hayati. 11:29-40 